\title{
RecA Proteins from Deinococcus geothermalis and Deinococcus murrayi - Cloning, Purification and Biochemical Characterisation
}

\author{
Marta Wanarska, Beata Krawczyk, Piotr Hildebrandt and Józef Kur
}

\begin{abstract}
Background: Escherichia coli RecA plays a crucial role in recombinational processes, the induction of SOS responses and mutagenic lesion bypasses. It has also been demonstrated that RecA protein is indispensable when it comes to the reassembly of shattered chromosomes in $\gamma$-irradiated Deinococcus radiodurans, one of the most radiation-resistant organisms known. Moreover, some functional differences between $E$. coli and D. radiodurans RecA proteins have also been shown.

Results: In this study, recA genes from Deinococcus geothermalis and Deinococcus murrayi, bacteria that are slightly thermophilic and extremely $\gamma$-radiation resistant, were isolated, cloned and expressed in E. coli. After production and purification, the biochemical properties of DgeRecA and DmuRecA proteins were determined. Both proteins continued to exist in the solutions as heterogenous populations of oligomeric forms. The DNA binding by DgeRecA and DmuRecA proteins is stimulated by $\mathrm{Mg}^{2+}$ ions. Furthermore, both proteins bind more readily to ssDNA when ssDNA and dsDNA are in the same reaction mixture. Both proteins are slightly thermostable and were completely inactivated in $10 \mathrm{~s}$ at $80^{\circ} \mathrm{C}$. Both proteins hydrolyze ATP and dATP in the presence of ssDNA or complementary ssDNA and dsDNA, but not in the absence of DNA or in the presence of dsDNA only, and dATP was hydrolyzed more rapidly than ATP. They were also able to promote DNA strand exchange reactions by a pathway common for other RecA proteins. However, we did not obtain DNA strand exchange products when reactions were performed on an inverse pathway, characteristic for RecA of D. radiodurans.

Conclusions: The characterization of DgeRecA and DmuRecA proteins made in this study indicates that the unique properties of $D$. radiodurans RecA are probably not common among RecA proteins from Deinococcus sp.
\end{abstract}

\section{Background}

Deinococcus geothermalis DSM 11302 and Deinococcus murrayi DSM 11303 are gram positive, nonmotile, spherical bacteria living in aerobic conditions. Cells that divide as tetrads are very common in both species. $D$. geothermalis and D. murrayi form orange-pigmented colonies, are slightly thermophilic with an optimum growth temperature of between $45-50^{\circ} \mathrm{C}$, but differ in optimum $\mathrm{pH}$ for growth. D. geothermalis DSM 11302 is slightly acidophilic and grows optimally at $\mathrm{pH} 6.5$, while D. murrayi DSM 11303 is slightly alcaliphilic with an optimum $\mathrm{pH}$ for growth of 8.0, although both species were isolated from the hot springs which had alkaline

\footnotetext{
* Correspondence: kur@pg.gda.pl

Department of Microbiology, Chemical Faculty, Gdańsk University of Technology, Narutowicza 11/12, 80-233 Gdańsk, Poland
}

$\mathrm{pH}$ values ranging from 8.6 to 8.9. D. geothermalis and D. murrayi were isolated from hot springs at São Pedro do Sul and Alcafache in central Portugal, respectively. The isolation of the acidophilic D. geothermalis strain from an alkaline site suggests that it can colonize the microenvironments of alkaline hot springs, such as biofilms, where the $\mathrm{pH}$ is lowered by other microorganisms [1]. D. geothermalis is also able to grow on metallic surfaces of printing paper machines and it is known as an efficient primary biofilm, formerly functioning as an adhesion platform for secondary biofilm bacteria [2-4]. $D$. geothermalis and D. murrayi display an increased gamma radiation resistance, as would normally be found in the genus Deinococcus [1]. The ability of these species to withstand high doses of ionizing radiation might result from an efficient RecA-dependent DSB repair

\section{() Biomed Central}


system, similar to that recently described in Deinococcus radiodurans [5-7].

RecA protein is a crucial DNA dependent ATPase involved in DNA repair and homologous recombination. RecA proteins are found in most microorganisms within the Bacteria domain, but some insects' and clams' endocellular bacterial symbionts such as Buchnera aphidicola APS, B. aphidicola Sg, Blochmannia floridanus, B. pennsylvanicus, Wigglesworthia glossinidia, Vesiomyosocius okutanii and Ruthia magnifica lack the recA gene [8-13]. Its analogues such as RadA [14] or Rad51 [15,16] are common in Archaea and Eucarya domains organisms. The product of the $u v s X$ gene of the bacteriophage T4 also displays many RecA-like properties [17].

RecA protein of E. coli, the best characterized RecA, is a multifunctional protein involved in homologous recombination [18], recombinational DNA repair [19] and SOS response to DNA damage and arrest of DNA replication [20]. RecA filaments on ssDNA acts as a coprotease which facilitates the autoproteolysis of LexA protein. This results in the derepression of genes in the SOS regulon $[21,22]$. RecA coprotease activity also facilitates the autocatalytic cleavage of the UmuD protein to the activated UmuD', a component of DNA polymerase $\mathrm{V}\left(\mathrm{UmuD}_{2}{ }_{2} \mathrm{C}\right)$ [23-27]. Moreover RecA nucleoprotein filament transfers RecA-ATP complex to polymerase V to form an active mutasome UmuD' ${ }_{2} \mathrm{C}$-RecA-ATP which catalyzes translesion DNA synthesis [28].

In vitro, in the presence of $\mathrm{Mg}^{2+}$ ions and $\mathrm{ATP}$, dATP or nonhydrolyzable ATP analogue ATP- $\gamma-\mathrm{S}$, RecA assembles around single-stranded DNA into a catalycally active helical filaments [29-32]. No ATP or dATP hydrolysis is needed for nucleoprotein filament formation, although these nucleotides are hydrolyzed by RecA in the presence of ssDNA [33], during the disassembly of filaments [34]. The active RecA filament is able to search out a homology between bound, single-stranded DNA and double-stranded molecules, and catalyzes the homologous pairing of DNA stands. These reactions also do not require cofactor hydrolysis and can occur in the presence of ATP- $\gamma-\mathrm{S}[35,36]$. The RecA protein of $E$. coli promotes both three-strand exchange reaction between homologous ssDNA and dsDNA molecules, and four-strand exchange between a duplex DNA with a single-stranded tail and a full dsDNA, where the strand exchange reaction is initiated in the single-stranded region $[37,38]$. Although homologous pairing and DNA strand exchange can occur in the three-strand exchange reaction without ATP hydrolysis [36], ATP hydrolysis renders RecA protein-mediated DNA strand exchange unidirectional (5' to $3^{\prime}$ with respect to the singlestranded DNA). In the presence of ATP- $\gamma$-S DNA strand exchange is bidirectional and limited in extent [39]. Moreover, ATP hydrolysis allows a heterologous sequence bypass in one of the DNA substrates [40,41], and is indispensable in the four-strand exchange reaction $[41,42]$. In contrast to E. coli RecA, the RecA protein of $D$. radiodurans is able to promote the DNA strand exchange through an inverse pathway, where the double-stranded DNA is bound first and the homologous single-stranded DNA second [43].

The aim of the present study was to clone, sequence and overexpress D. geothermalis DSM 11302 and D. murrayi DSM 11303 recA genes in E. coli. A biochemical characterization of recombinant $D g e \operatorname{Rec} A$ and $D m u$ RecA proteins was performed.

\section{Results}

Cloning, expression and purification of $D$. geothermalis and $D$. murrayi RecA proteins

The primers for amplification of D. geothermalis DSM $11302 \mathrm{rec} A$ gene were designed on the basis of the known recA gene sequence of $D$. geothermalis DSM 11300 [GenBank: CP000359]. The obtained PCR product was cloned into a PCR-Blunt vector and sequenced. The nucleotide sequence of $D$. geothermalis DSM 11302 recA gene is available from the GenBank database under accession number EF447285.

The predicted $D g e$ RecA monomer protein contains 358 amino acid residues. A homology search performed using a version 3 FASTA programme at the EBI (European Bioinformatics Institute) revealed that the amino acid sequence of D. geothermalis DSM 11302 RecA shares $100 \%$ identity with $D$. geothermalis DSM 11300 RecA protein [GenBank: ABF46432], 87.6\% identity and 95.9\% similarity with $D$. radiodurans $\mathrm{R} 1$ RecA protein [GenBank: AAF11887], 71.1\% identity and 91.6\% similarity with Thermus aquaticus YT-1 RecA protein [GenBank: AAA19796], 71.0\% identity and 89.8\% similarity with T. thermophilus HB8 or T. thermophilus HB27 RecA proteins [GenBank: BAD71641 and AAS81808, respectively], $70.6 \%$ identity and $89.8 \%$ similarity with Meiothermus ruber DSM 1279 RecA protein [GenBank: ADD27511], 67.6\% identity and $87.2 \%$ similarity with M. silvanus DSM 9946 RecA protein [GenBank: ADH62770], and $60.9 \%$ identity and $84.1 \%$ similarity with E. coli RecA protein [GenBank: CAA23618].

The D. murrayi DSM 11303 recA gene sequence was obtained using a two step procedure. In first step, the internal fragment of the $r e c A$ gene was amplified using degenerated primers designed on the basis of an alignment of $r e c A$ gene sequences from bacteria belonging to the Deinococcus-Thermus group. In the second step, flanking regions were amplified by inverse PCR. The obtained partial sequences of the $D$. murrayi recA gene were then aligned and the primers for amplification of the gene were designed. Afterwards, the PCR product was cloned using a CloneJETTM PCR Cloning Kit and 
sequenced. The nucleotide sequence of $D$. murrayi DSM 11303 recA gene was deposited in the GenBank database under accession number HM004587.

The DmuRecA protein contains 359 amino acid residues. The deduced amino acid sequence of $D$. murrayi DSM 11303 RecA shows 94.4\% identity and 97.8\% similarity with $D$. geothermalis DSM 11300 RecA protein, $86.9 \%$ identity and $96.9 \%$ similarity with $D$. radiodurans R1 RecA protein, 71.4\% identity and $90.7 \%$ similarity with Thermus aquaticus YT-1 RecA protein, $70.7 \%$ identity and $89.2 \%$ similarity with $T$. thermophilus HB8 RecA protein, $70.3 \%$ identity and $89.5 \%$ similarity with Meiothermus ruber DSM 1279 RecA protein, 69.6\% identity and $87.8 \%$ similarity with $T$. thermophilus HB27 RecA protein, $67.0 \%$ identity and $85.7 \%$ similarity with M. silvanus DSM 9946 RecA protein, and 62.3\% identity and $86.0 \%$ similarity with $E$. coli RecA protein. The multiple sequence alignment of RecA proteins from bacteria of the genus Deinococcus, Thermus and Meiothermus, and $E$. coli RecA protein is shown in Figure 1.

In the next step, recombinant plasmids (pET-30Ek/ LIC-DgeRecA and pET-30Ek/LIC-DmuRecA for biosynthesis of RecA proteins from $D$. geothermalis and $D$. murrayi in E. coli T7 expression system) were constructed. After recA gene expression in the E. coli BLR (DE3) $\left(r e c A^{-}\right)$cells, $D g e$ RecA protein was purified by heat treatment of lysate at $60^{\circ} \mathrm{C}$ for $20 \mathrm{~min}$ and ion exchange chromatography. In the case of purification of $D m u R e c A$ protein heat treatment was omitted due to its low thermostability. The purity of DgeRecA and DmuRecA proteins at every step of production and purification was checked by SDS-PAGE after Coomassie Brilliant Blue R staining (Figure 2).

The applied overexpression and purification systems produced about $63 \mathrm{mg}$ of DgeRecA and $50 \mathrm{mg}$ of $D m u$ RecA proteins from $1 \mathrm{~L}$ of $E$. coli culture.

Analysis of the purified proteins by SDS-PAGE revealed major bands with a molecular mass of about 40 kDa for both $D g e$ RecA and DmuRecA proteins (Figure 2 , lanes 6 and 11), which agreed with the amino acid sequence calculation; $38.157 \mathrm{kDa}$ and $38.170 \mathrm{kDa}$, respectively. Summary of the purification process is shown in Table 1.

\section{Oligomeric states of DgeRecA and DmuRecA proteins} Oligomeric states of $D g e \operatorname{Rec} A$ and $D m u R e c A$ proteins at a concentration range between 3 and $58 \mu \mathrm{M}$ in $25 \mathrm{mM}$ potassium phosphate buffer $\mathrm{pH} 7.5$ containing $1 \mathrm{M} \mathrm{KCl}$ were analyzed by gel filtration. The oligomeric states of examined proteins depend highly on their level of concentration. At high concentrations in solutions (58 and $29 \mu \mathrm{M})$ both RecA proteins exist as a heterogenous population of oligomeric forms ranging in size from dimers (elution volume near $14 \mathrm{ml}$ ) to long protein filaments and highly aggregated structures (elution near the void volume of $8.25 \mathrm{ml}$ ). Furthermore in such conditions, a greater percentage of DgeRecA and DmuRecA proteins exist as big oligomers, although in the case of DmuRecA significant amounts of dimers and trimers (elution volume near 14 and $13 \mathrm{ml}$, respectively) were also present. At 6 and $3 \mu \mathrm{M}$ concentrations both proteins eluted at volumes corresponding mainly to the small oligomers and probably monomers in the case of DmuRecA protein (Figure 3).

\section{ssDNA-binding properties}

To determine the ability of DgeRecA and DmuRecA proteins to bind ssDNA, we carried out agarose gel mobility assays with 5 '-end fluorescein-labelled $(\mathrm{dT})_{35}$-oligonucleotides. The assays were carried out with increasing concentration of $\mathrm{Mg}^{2+}$ ions and at various temperatures between 25 and $75^{\circ} \mathrm{C}$. We observed, that ssDNA binding by RecA proteins was stimulated by $\mathrm{Mg}^{2+}$ ions and was the most efficient at 8 and $10 \mathrm{mM} \mathrm{Mg}^{2+}$ (Figure 4). DgeRecA was able to bind oligo $(\mathrm{dT})_{35}$ at temperatures between 25 and $58^{\circ} \mathrm{C}$ while $D m u R e c A$ exhibited activity between 25 and $54.5^{\circ} \mathrm{C}$, although at the highest temperatures, $58^{\circ} \mathrm{C}$ for $D g e \operatorname{Rec} A$ and $54.5^{\circ} \mathrm{C}$ for $D m u R e c A$, the ssDNA binding was very slight (Figure 5 ).

\section{dsDNA-binding properties}

We examined also the ability of RecA proteins from $D$. geothermalis and D. murrayi to bind dsDNA in the absence of magnesium ions and in the presence of 10 $\mathrm{mM} \mathrm{Mg}^{2+}$. Both proteins were able to bind $600 \mathrm{bp}$ PCR products and the dsDNA binding was stimulated by $\mathrm{Mg}^{2+}$ ions as well as in the case of ssDNA binding (Figure $6 \mathrm{~A}$ and $6 \mathrm{~B}$, lanes 2 and 3 ). Afterwards, to determine what kind of DNA is more readily bound by $D g e$ RecA and $D m u$ RecA proteins we carried out the reactions where 5'-end fluorescein-labelled oligo $(\mathrm{dT})_{35}$ and $600 \mathrm{bp}$ PCR product were in the same test tube. When ssDNA and $\mathrm{dsDNA}$ were included in the reaction mixture, ssDNA was bound preferentially by both RecA proteins, both in the absence and presence of magnesium ions (Figure 6A and 6B, lanes 5 and 6). We observed also that DmuRecA bound dsDNA more efficient than DgeRecA in all conditions tested.

\section{Thermostability of DgeRecA and DmuRecA proteins}

Thermostability of RecA proteins was characterized as the longest time period needed for complete loss of visible ssDNA binding activity investigated by gel-mobility shift assay after incubation at given temperature. Dge RecA and $D m u R e c A$ were incubated at temperatures between 50 and $80^{\circ} \mathrm{C}$ for $10 \mathrm{~s}-180$ minutes, in the absence or in the presence of $10 \mathrm{mM} \mathrm{Mg}^{2+}$. No significant loss of protein activity was observed after 


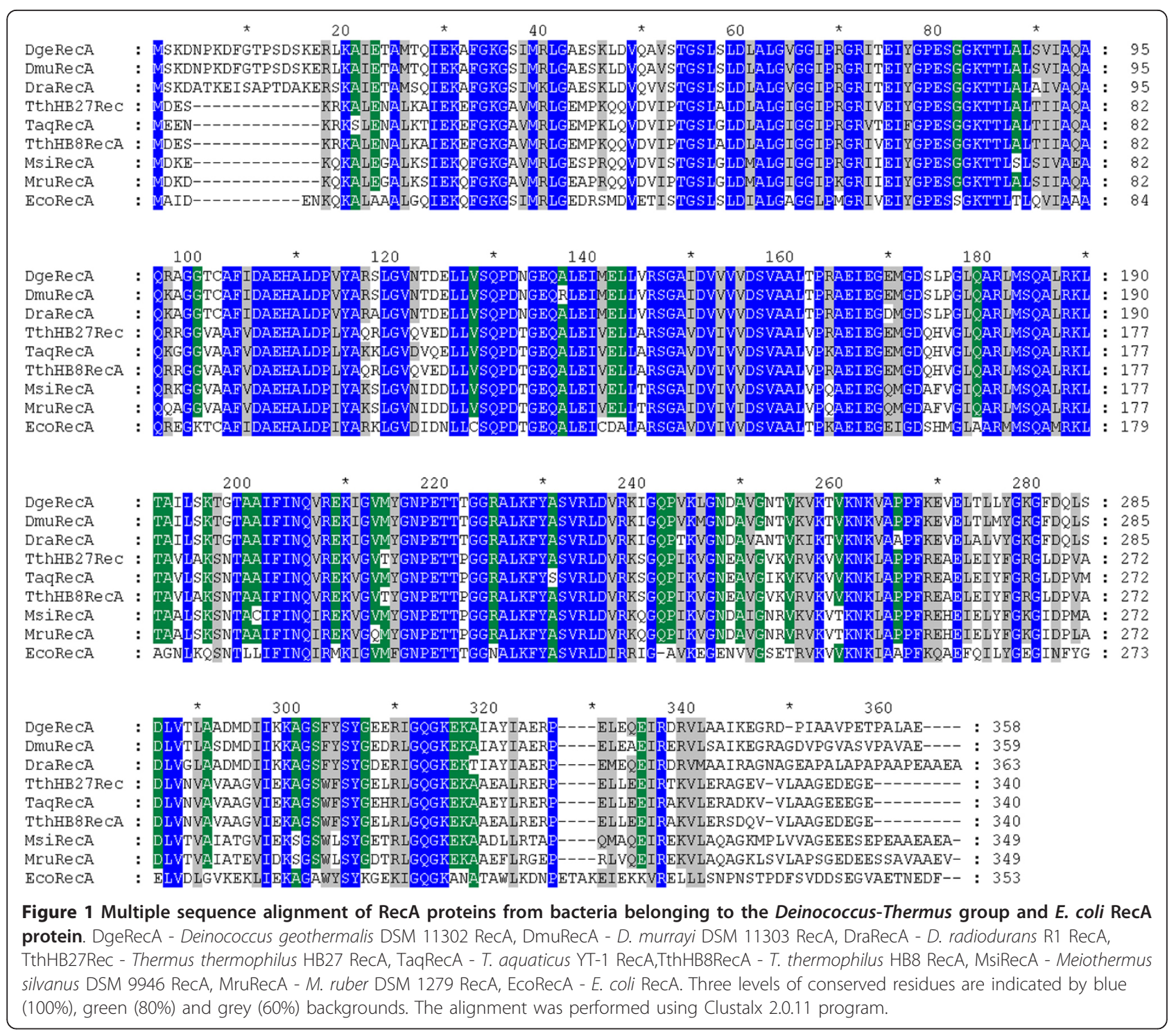

incubation at $50^{\circ} \mathrm{C}$ for $180 \mathrm{~min}$. DgeRecA was also stable for $180 \mathrm{~min}$ at $57^{\circ} \mathrm{C}$, while $\mathrm{DmuRecA}$ lost activity within $15 \mathrm{~min}$ at this temperature. Both proteins incubated at higher temperatures displayed lower thermostability and at $80^{\circ} \mathrm{C}$ were completely inactivated in $10 \mathrm{~s}$. The RecA protein from $D$. geothermalis was more thermostable than RecA from D. murrayi (Table 2). Moreover magnesium ions have no effect on the thermal stability neither DgeRecA nor DmuRecA.

\section{ATP and dATP hydrolysis}

ATP and dATP hydrolysis catalyzed by RecA proteins from $D$. geothermalis and D. murrayi was monitored with a coupled spectrophotometric assay. We studied the DNA and temperature dependence of DgeRecA and DmuRecA activity. We also measured the ATPase activity of both proteins at various concentrations of ATP and dATP to determine their kinetic parameters.

We found no detectable ATPase and dATPase activities of DgeRecA and DmuRecA in the absence of DNA and in the presence of dsDNA only. Both proteins however were able to hydrolyze ATP and AATP in the presence of ssDNA and in the DNA strand exchange conditions, although the rates of ssDNA-dependent ATP or dATP hydrolysis were higher. Furthermore, both proteins hydrolyzed dATP more rapidly than ATP either in the presence of ssDNA or ssDNA and dsDNA in the same reaction mixture (Tables 3 and 4 ). The rates of ssDNA-dependent ATP and dATP hydrolysis increased with temperature for both proteins and peaked at $42^{\circ} \mathrm{C}$ and $45^{\circ} \mathrm{C}$ for DmuRecA and DgeRecA, respectively (Table 5 ). Kinetic parameters for ATPase 

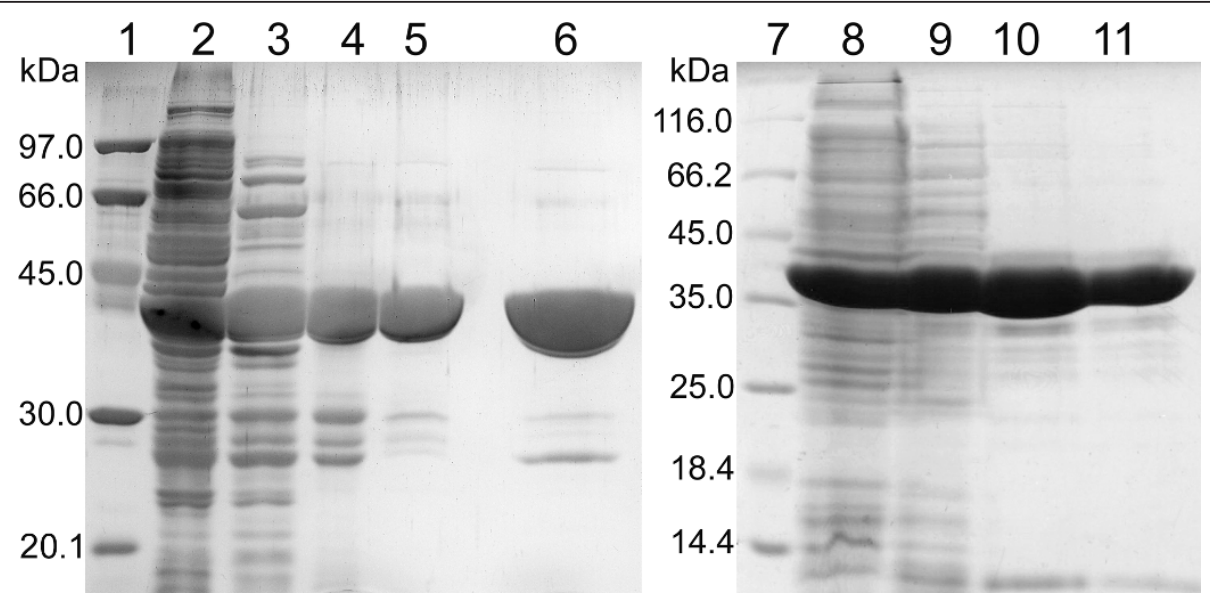

Figure 2 SDS-PAGE analysis of the fractions obtained by expression and purification of DgeRecA and DmuRecA proteins. Lane 1 - LMW SDS Marker (Amersham Biosciences AB): 97, 66, 45, 30, 20.1 and $14.4 \mathrm{kDa}$, lane 2 - cell extract of the E. coli BLR(DE3) + pET-30Ek/LIC-DgeRecA, lane 3 - DgeRecA after heat treatment, lane 4 - DgeRecA after chromatography on Fractogel EMD DEAE column, lane 5 - DgeRecA after chromatography on ResourceQ column, lane 6 - DgeRecA after chromatography on MonoQ column, lane 7 - Unstained Protein Molecular Weight Marker (Fermentas): 116, 66.2, 45, 35, 25, 18.4 and 14.4 kDa, lane 8 - cell extract of E. coli BLR(DE3) + pET-30Ek/LIC-DmuRecA, lane 9 DmuRecA after chromatography on Fractogel EMD DEAE column, lane 10 - DmuRecA after chromatography on ResourceQ column, lane 11 DmuRecA after chromatography on MonoQ column.

and dATPase activity of DgeRecA and DmuRecA proteins are displayed in Tables 6 and 7.

\section{DNA strand exchange reactions}

The ability of $D g e$ RecA and $D m u$ RecA proteins to promote DNA strand exchange reaction was investigated in the presence of ATP or dATP, ATP-regenerating system and DgeSSB protein (obtained according to a procedure by Filipkowski et al. [44]), at $42^{\circ} \mathrm{C}$ for $D m u R e c A$ and $45^{\circ}$ C for DgeRecA. At first, filaments composed of ssDNA and RecA protein were formed. Afterwards, linear complementary dsDNA was added to start DNA strand

Table 1 Summary of the purification of DgeRecA and DmuRecA proteins obtained from $1 \mathrm{~L}$ of $E$. coli BLR(DE3) culture

\begin{tabular}{|c|c|c|c|}
\hline Protein & $\begin{array}{l}\text { Purification } \\
\text { step }\end{array}$ & $\begin{array}{l}\text { Total protein } \\
\text { (mg) }\end{array}$ & $\begin{array}{l}\text { Recovery of protein } \\
\text { (\%) }\end{array}$ \\
\hline \multirow[t]{6}{*}{ DgeRecA } & Cell extract & 760 & 100 \\
\hline & Heat treatment & 341 & 45 \\
\hline & Fractogel EMD & 121 & 16 \\
\hline & DEAE column & & \\
\hline & $\begin{array}{l}\text { ResourceQ } \\
\text { column }\end{array}$ & 75 & 10 \\
\hline & MonoQ column & 63 & 8 \\
\hline \multirow[t]{5}{*}{ DmuRecA } & Cell extract & 510 & 100 \\
\hline & Fractogel EMD & 356 & 70 \\
\hline & DEAE column & & \\
\hline & $\begin{array}{l}\text { ResourceQ } \\
\text { column }\end{array}$ & 93 & 18 \\
\hline & MonoQ column & 50 & 10 \\
\hline
\end{tabular}

exchange. After incubation and at various time periods, reactions were halted by protein degradation. As shown in Figure 7, DgeRecA and DmuRecA promoted homologous DNA strand exchange either in the presence of ATP or dATP as evidenced by forming nicked circular dsDNA products, although the products appeared earlier when reactions were performed with ATP. Moreover DNA strand exchange occurred faster when DmuRecA was used. We also performed DNA strand exchange reactions via an inverse pathway, where RecA proteins were preincubated with the linear dsDNA and circular ssDNA was then added to initiate reactions, however we do not observe nicked circular dsDNA products even after $90 \mathrm{~min}$ of incubation.

\section{Discussion}

In this article, the cloning, purification and initial characterization of RecA proteins from slightly thermophilic and extremely radioresistant bacteria $D$. geothermalis and D. murrayi are described. The DgeRecA and DmuRecA exhibit many properties common to this class of proteins. In the absence of DNA both proteins selfassemble into a variety of oligomers, their size strongly depending on the concentration of protein in the solution, a characteristic of RecA proteins. Although oligomeric populations of $T$. aquaticus and T. thermophilus RecA proteins contain a large percentage of hexamers [45-48], it was impossible in our study to determine the preferred oligomeric state of DgeRecA and DmuRecA.

RecA proteins of D. geothermalis and D. murrayi bind both ssDNA and dsDNA like other RecA proteins. 


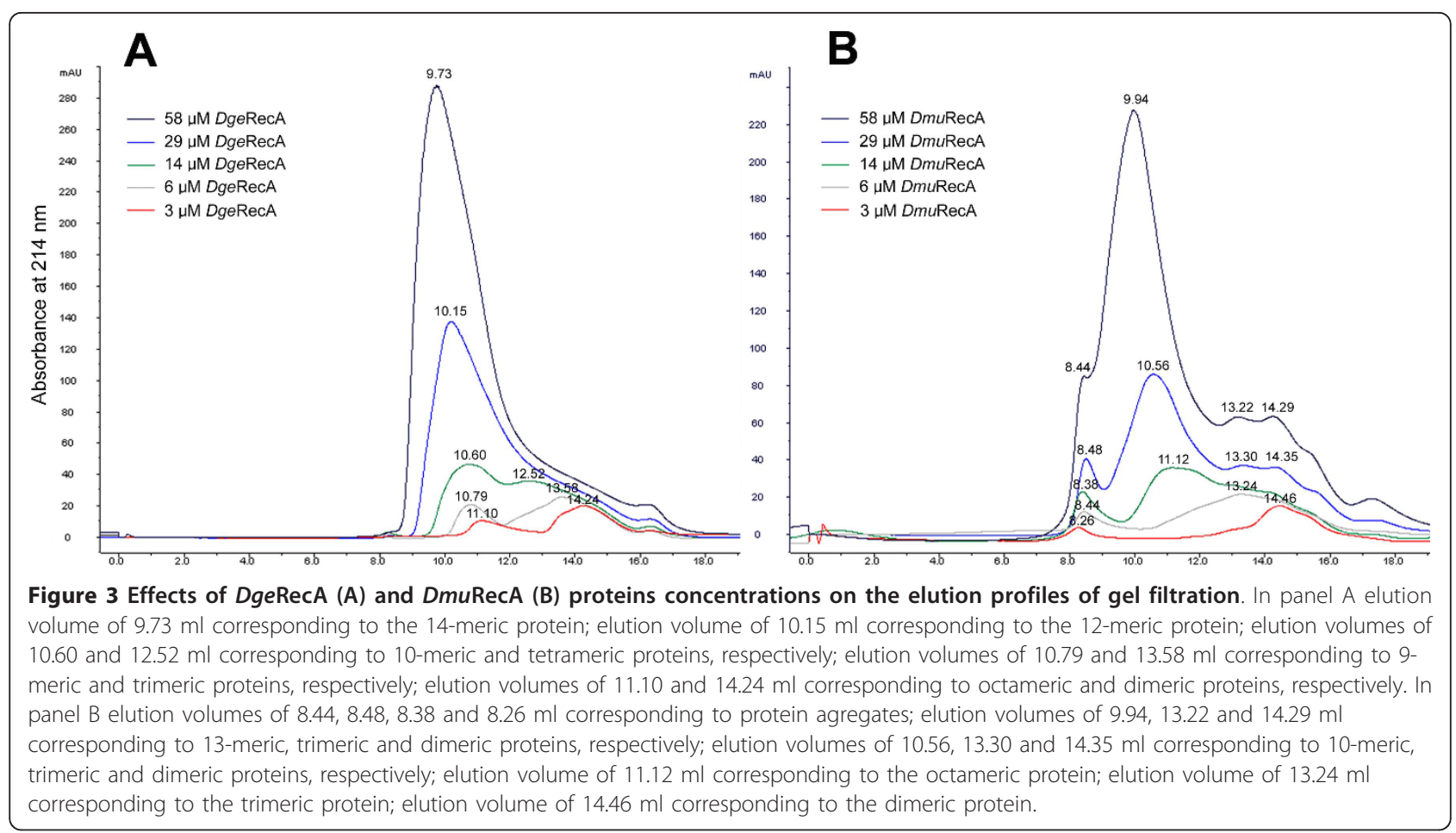

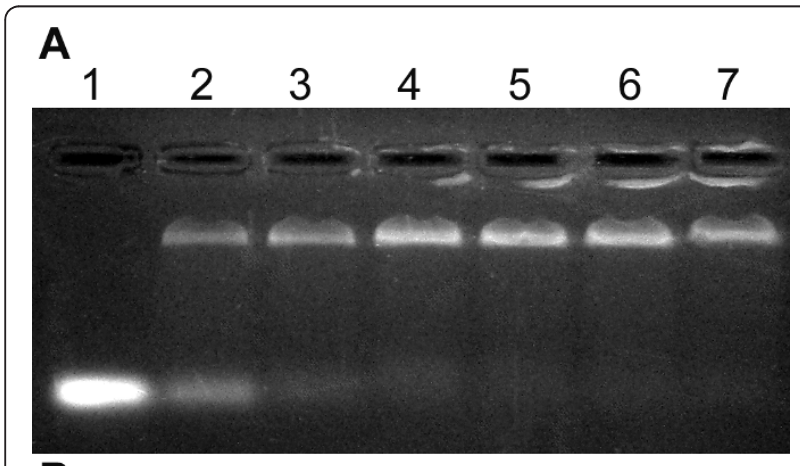

B

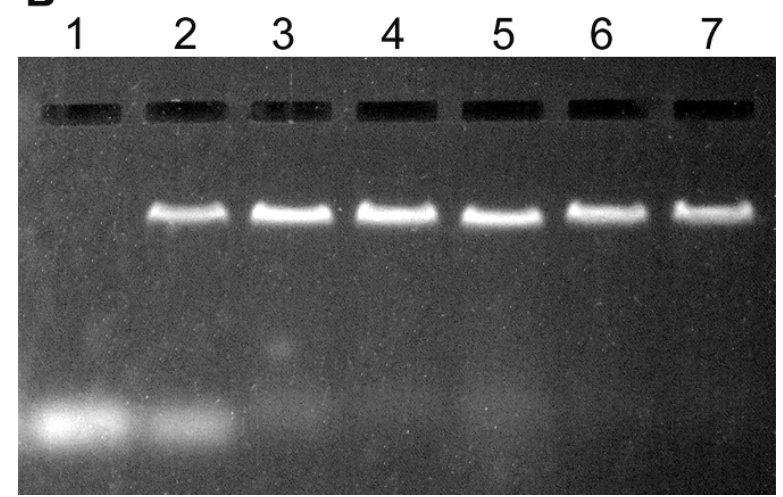

Figure 4 Binding of $D g e \operatorname{Rec} A(\mathrm{~A})$ and $D m u \operatorname{Rec} A(\mathrm{~B})$ to $5^{\prime}$-end fluorescein-labeled $(\mathrm{dT})_{35}$-oligonucleotides in the presence of various $\mathrm{Mg}^{2+}$ ions concentrations at $37^{\circ} \mathrm{C}$ - gel mobility shift assays. Lane 1 - oligo $(\mathrm{dT})_{35}$, lane $2-0 \mathrm{mM} \mathrm{Mg}^{2+}$, lane $3-2 \mathrm{mM}$ $\mathrm{Mg}^{2+}$, lane $4-4 \mathrm{mM} \mathrm{Mg}^{2+}$, lane $5-6 \mathrm{mM} \mathrm{Mg}^{2+}$, lane $6-8 \mathrm{mM}$ $\mathrm{Mg}^{2+}$, lane 7 - $10 \mathrm{mM} \mathrm{Mg}^{2+}$.
However, it was demonstrated that RecA protein of $D$. radiodurans binds preferentially to double-stranded DNA even when ssDNA is present in the reaction mixture $[49,50]$. In contrast to DraRecA, DgeRecA and $D m u R e c A$ bind more readily to single-stranded DNA when both ssDNA and dsDNA are in the same reaction mixture.

RecA proteins of D. geothermalis and D. murrayi are DNA-dependent ATPases. In the absence of DNA, ATP or AATP, hydrolysis was not detected. A similar result was demonstrated for D. radiodurans RecA [50]. In contrast, ATP hydrolysis in the absence of exogenous DNA was detected for $E$. coli RecA protein, although the rate was significantly reduced [33]. Unlike DraRecA protein $[49,50]$, the $D g e \operatorname{RecA}$ and $D m u$ RecA proteins were not able to perform ATP or dATP hydrolysis in the presence of dsDNA at $\mathrm{pH}$ 7.5. The same results were shown for $T$. thermophilus and E. coli RecA proteins [33,51], although EcoRecA protein hydrolyses ATP in the presence of dsDNA at lower $\mathrm{pH}$ (optimum near pH 6) [33]. The ATP and dATP hydrolysis catalyzed by RecA proteins of $D$. geothermalis and D. murrayi was stimulated by singlestranded DNA, and dATP was hydrolyzed faster than ATP. These results are consistent with the results obtained for RecA proteins of $E$. coli and D. radiodurans [33,49].

Both DgeRecA and DmuRecA as well as EcoRecA and DraRecA were able to promote DNA strand exchange using ATP or dATP as a cofactor [41,49]. However, in the presence of dATP nicked circular heteroduplex 


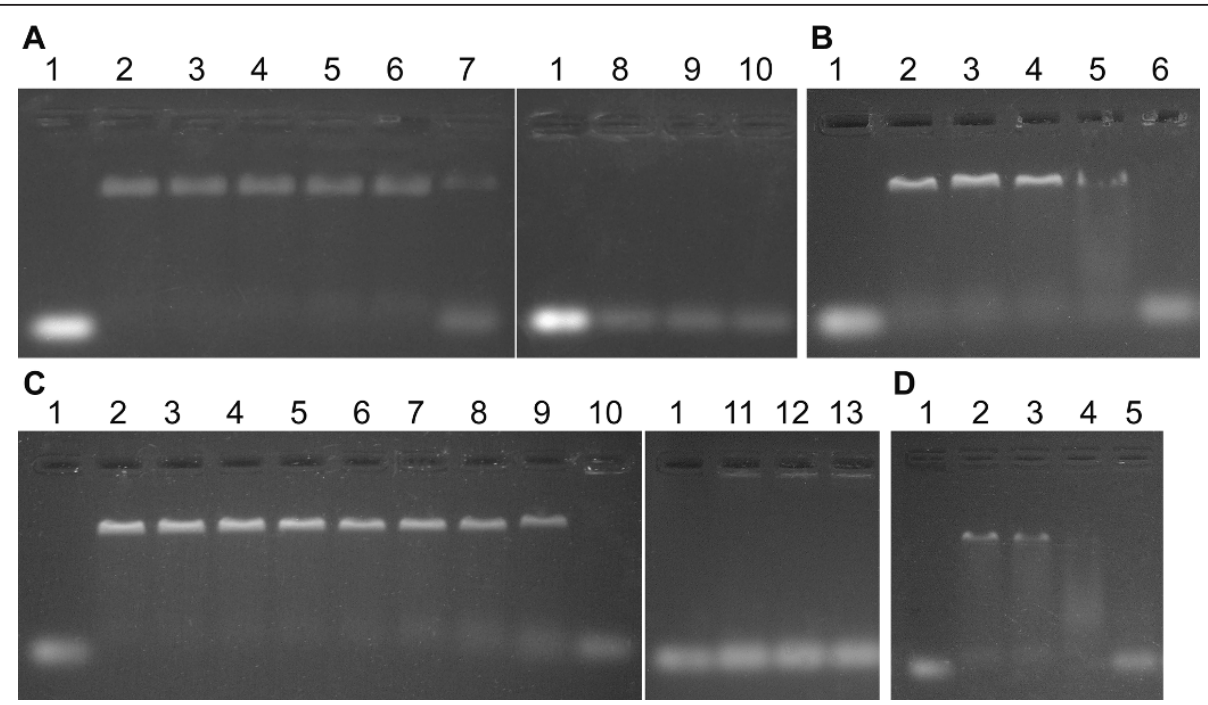

Figure 5 Binding of $\operatorname{DgeRec}(A, B)$ and $\operatorname{DmuRec} A(C, D)$ to $5^{\prime}$-end fluorescein-labeled $(\mathrm{dT})_{35}$-oligonucleotides in the presence of 10 $\mathrm{mM} \mathrm{Mg}{ }^{2+}$ at various temperatures - gel mobility shift assays. Panel $\mathrm{A}$ : lane 1 - oligo $(\mathrm{dT})_{35}$, lane $2-25.0^{\circ} \mathrm{C}$, lane $-3-31.1^{\circ} \mathrm{C}$, lane $4-38.2^{\circ} \mathrm{C}$, lane $5-45.3^{\circ} \mathrm{C}$, lane $6-51.1^{\circ} \mathrm{C}$, lane $-7-58.0^{\circ} \mathrm{C}$, lane $8-65.3^{\circ} \mathrm{C}$, lane $9-72.2^{\circ} \mathrm{C}$, lane $10-75.0^{\circ} \mathrm{C}$; panel B: lane $1-$ oligo $\left.(\mathrm{dT})\right)_{35}$, lane $2-55.0^{\circ} \mathrm{C}$, lane $3-55.9^{\circ} \mathrm{C}$, lane $4-57.1^{\circ} \mathrm{C}$, lane $5-58.0^{\circ} \mathrm{C}$, lane $6-59.4^{\circ} \mathrm{C}$; panel $\mathrm{C}$ : lane 1 - oligo $(\mathrm{dT})_{35}$, lane $2-25.0^{\circ} \mathrm{C}$, lane $-3-25.9^{\circ} \mathrm{C}$, lane $4-28.7^{\circ} \mathrm{C}$, lane $5-$ $33.1^{\circ} \mathrm{C}$, lane $6-37.9^{\circ} \mathrm{C}$, lane $-7-42.6^{\circ} \mathrm{C}$, lane $8-47.4^{\circ} \mathrm{C}$, lane $9-52.1^{\circ} \mathrm{C}$, lane $10-56.9^{\circ} \mathrm{C}$, lane $11-61.2^{\circ} \mathrm{C}$, lane $12-64.1^{\circ} \mathrm{C}$, lane $13-65.0^{\circ} \mathrm{C}$; panel $\mathrm{D}$ : lane 1 - oligo $(\mathrm{dT})_{35}$, lane $2-52.0^{\circ} \mathrm{C}$, lane $3-53.2^{\circ} \mathrm{C}$, lane $4-54.5^{\circ} \mathrm{C}$, lane $5-55.6^{\circ} \mathrm{C}$.

products formed more slowly than in the presence of ATP. Similar results were also obtained for RecA protein of $D$. radiodurans [49].

The major difference between $E$. coli and D. radiodurans RecA proteins is the ability to promote DNA strand exchange using inverse pathways. The EcoRecA initiates DNA strand exchange with a filament bound to the ssDNA, while the DraRecA binds dsDNA first and homologous ssDNA second [43]. In our study, we did not obtained the product of DNA strand exchange reactions initiated with $D g e$ RecA-dsDNA or DmuRecAdsDNA filaments, although Sghaier et al. [52] demonstrated that RecA protein of D. geothermalis is able to promote DNA exchange reactions through normal and inverse pathways. The difference in results obtained by Sghaier et al. and us may be due to differences in the conditions of the DNA strand exchange reactions, especially the differences in the length of dsDNA fragments used. In our study, we performed DNA strand exchange reactions between full length linear M13mp18 dsDNA (7249 bp) and circular M13mp18 ssDNA, whereas Sghaier et al. used a short fragment of $\Phi$ X174 dsDNA obtained by digestion with HincII endonuclease (the longest DNA fragment obtained by HincII digestion of ФX174 RFI and its size was $1057 \mathrm{bp}$ ) and circular ФX174 ssDNA (5386 nt).

A

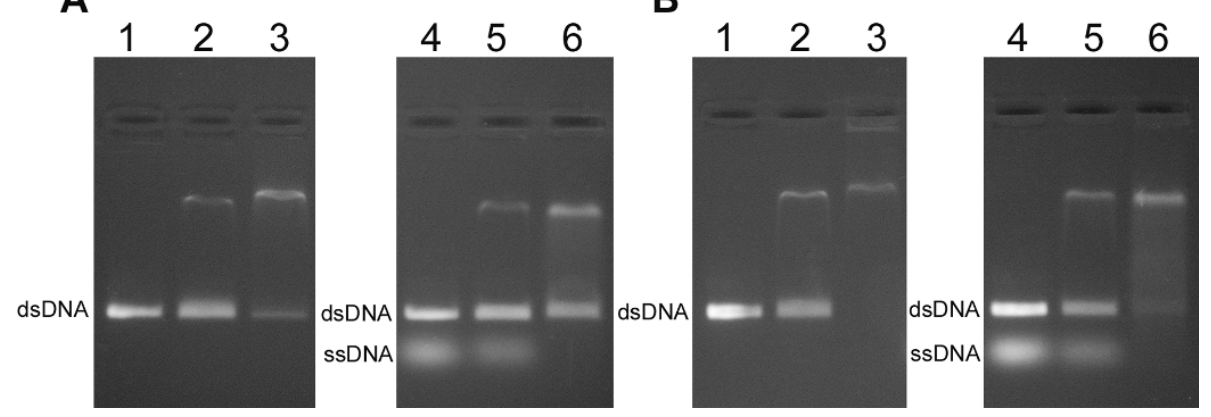

Figure 6 Binding of DgeRecA (A) and DmuRecA (B) to dsDNA in the absence and in the presence of heterologous ssDNA - gel mobility shift assays. Lane 1 - 600 bp PCR product, lane 2 - dsDNA binding products obtained in the absence of Mg ${ }^{2+}$ ions, lane 3 - dsDNA binding products obtained in the presence of $10 \mathrm{mM} \mathrm{Mg}{ }^{2+}$ ions, lane 4 - 600 bp PCR product and 5'-end fluorescein-labeled oligo(dT) 35 , lane 5 DNA binding products obtained in the absence of $\mathrm{Mg}^{2+}$ ions, lane 6 - DNA binding products obtained in the presence of $10 \mathrm{mM}$ Mg ${ }^{2+}$ ions. 
Table 2 Thermostability of DgeRecA and DmuRecA proteins

\begin{tabular}{ccc}
\hline Temperature $\left({ }^{\circ} \mathrm{C}\right)$ & $\begin{array}{c}\text { Maximum incubation time (min) } \\
\text { DgeRecA }\end{array}$ & $\begin{array}{c}\text { DmuRecA } \\
\text { Dm }\end{array}$ \\
\hline 50 & 180 & 180 \\
57 & 180 & 15 \\
62 & 20 & 8 \\
71 & 1 & 0.67 \\
75 & 0.50 & 0.33 \\
80 & $0^{\text {a }}$ & $0^{\text {a }}$ \\
\hline
\end{tabular}

${ }^{a}$ Complete lost of activity after shorter than $10 \mathrm{~s}$ incubation time

RecA proteins of D. geothermalis and D. murrayi are active at elevated temperatures similarly to RecA of $T$. thermophilus. The optimum temperature for TthRecA ATPase activity is $65^{\circ} \mathrm{C}$ [51], and for Dge RecA and $D m u R e c A$ proteins is 45 and $42^{\circ} \mathrm{C}$, respectively. However, they are able to bind ssDNA at temperatures reaching $54.5^{\circ} \mathrm{C}$ for $D m u R e c A$ and $58^{\circ} \mathrm{C}$ for DgeRecA. Moreover, the thermostability assay revealed that the $D g e$ RecA and DmuRecA are less thermostable than $T t h R e c A$ which remains still active after a 10-s incubation at $85^{\circ} \mathrm{C}$ (data not shown), whereas DgeRecA and $D m u R e c A$ are completely inactivated in $10 \mathrm{~s}$ at $80^{\circ} \mathrm{C}$.

\section{Conclusions}

The properties of RecA proteins of slightly thermophilic and extremely radioresistant bacteria $D$. geothermalis and D. murrayi obtained in this study demonstrate that they are close functional homologues of the other RecA proteins. Although it has previously been shown that the RecA protein of the extremely radioresistant bacterium D. radiodurans exhibits some unusual properties, in our study we did not observe such properties in the case of $D g e$ RecA and DmuRecA. This suggests the uniqueness of DraRecA even among RecA proteins from microorganisms of the Deinococcus genus. On the other hand, it has been also demonstrated that the dsDNA-binding preferences displayed by DraRecA are not necessary for double-stranded breaks repair in $\gamma$-irradiated $D$. radiodurans. The rapid reconstruction of an intact genome occurring through an extended synthesis-dependent strand

Table 3 Effect of DNA on the rate of ATP and dATP hydrolysis catalyzed by DgeRecA.

\begin{tabular}{ccccc}
\hline Substrate & \multicolumn{4}{c}{ Rate of hydrolysis $(\mu \mathrm{M} / \mathrm{min})$} \\
& $\begin{array}{c}\text { absence of } \\
\text { DNA }\end{array}$ & dsDNA & ssDNA & $\begin{array}{c}\text { ssDNA and } \\
\text { dsDNA }^{\text {a }}\end{array}$ \\
\hline ATP & not detected & not & $26.8 \pm$ & $20.3 \pm 0.36$ \\
dATP & not detected & not & $31.6 \pm$ & $23.7 \pm 0.43$ \\
& & detected & 0.63 &
\end{tabular}

Reactions conditions: $37^{\circ} \mathrm{C}, 2.27 \mathrm{mM}$ ATP or dATP.

${ }^{\text {a }}$ DNA strand exchange conditions
Table 4 Effect of DNA on the rate of ATP and dATP hydrolysis catalyzed by DmuRecA

\begin{tabular}{ccccc}
\hline Substrate & \multicolumn{4}{c}{ Rate of hydrolysis $(\mu \mathrm{M} / \mathrm{min})$} \\
& $\begin{array}{c}\text { absence of } \\
\text { DNA }\end{array}$ & dsDNA & ssDNA & $\begin{array}{c}\text { ssDNA and } \\
\text { dsDNA }{ }^{\mathbf{a}}\end{array}$ \\
\hline ATP & not detected & not & $34.4 \pm$ & $21.2 \pm 0.44$ \\
& detected & 0.58 & \\
dATP & not detected & not & $47.0 \pm$ & $24.6 \pm 0.49$ \\
& & detected & 0.71 & \\
\hline
\end{tabular}

Reactions conditions: $37^{\circ} \mathrm{C}, 2.27 \mathrm{mM}$ ATP or dATP.

${ }^{\text {a }}$ DNA strand exchange conditions

annealing process (ESDSA) followed by a DNA recombination requires a 5'-3' single-stranded DNA exonuclease RecJ, a RecQ helicase and a RecF, RecO and RecR proteins to act together to promote loading of RecA onto single-stranded DNA [53].

\section{Methods}

Bacterial strains and growth conditions

D. geothermalis DSM 11302 and D. murrayi DSM 11303 were purchased from Deutsche Sammlung von Mikroorganismen und Zellkulturen (Braunschweig, Germany). They were grown in $50 \mathrm{ml}$ modified Luria-Bertani medium $\mathrm{pH} 7.2$ containing $1 \mathrm{~g}$ peptone $\mathrm{K}, 1 \mathrm{~g}$ yeast extract and $7.4 \mathrm{~g}$ sea salt in $1000 \mathrm{ml}$ distilled water. D. geothermalis was grown for $30 \mathrm{~h}$ at $50^{\circ} \mathrm{C}$ and $D$. murrayi was grown for $30 \mathrm{~h}$ at $47^{\circ} \mathrm{C}$. Afterwards genomic DNA was isolated using Genomic Mini AX Bacteria (A\&A Biotechnology, Poland).

\section{Cloning of the $D$. geothermalis recA gene}

The $r e c A$ gene was amplified by PCR using genomic DNA from D. geothermalis DSM 11302 as the template. The primers used were: DGRAFNde 5' CGACATATGAGCAAGGAACAACCCCAAGGA 3', containing recognition site for $N d e$ I endonuclease (underlined) and DGRARHnd 5' ACAAAGCTTACTCTGCCAAGGCGGGC 3', containing recognition site for HindIII endonuclease (underlined). The start and stop codons are bolded. The reaction mixture consisted of $0.13 \mu \mathrm{g}$ of D. geothermalis DNA, $0.2 \mu \mathrm{M}$ of each primer, $200 \mu \mathrm{M}$ of each dNTP, $2 \mathrm{mM} \mathrm{MgSO}_{4}$ and $1 \mathrm{U}$ of Delta3 DNA polymerase (DNA-Gdańsk, Poland) in $1 \times$ PCR buffer $(20 \mathrm{mM}$ Tris- $\mathrm{HCl} \mathrm{pH} 8.8,10 \mathrm{mM} \mathrm{KCl}, 10$ $\mathrm{mM}\left(\mathrm{NH}_{4}\right)_{2} \mathrm{SO}_{4}, 0.1 \%$ Triton X-100). PCR reaction was performed using the following conditions: $95^{\circ} \mathrm{C}-2 \mathrm{~min}$, $\left(95^{\circ} \mathrm{C}-1 \mathrm{~min}, 61^{\circ} \mathrm{C}-1 \mathrm{~min}, 72^{\circ} \mathrm{C}-1 \mathrm{~min} ; 30\right.$ cycles $)$, $72^{\circ} \mathrm{C}-5 \mathrm{~min}$. The PCR product was cloned into the pCR-Blunt vector (Invitrogen, Carlsbad, California, USA) and sequenced. The obtained pCR-Blunt-NdeI$D g e$ RecA-HindIII plasmid was then digested with NdeI and HindIII endonucleases, and the DNA fragment containing the $r e c A$ gene was cloned into pET-30 Ek/LIC 
Table 5 Effect of temperature on the rate of ssDNA-dependent ATP and dATP hydrolysis catalyzed by DgeRecA and DmuRecA

\begin{tabular}{ccccccc}
\hline Protein & Substrate & \multicolumn{3}{c}{ Rate of hydrolysis $(\boldsymbol{\mu M} / \mathbf{m i n})$} \\
& & $\mathbf{3 2 ^ { \circ } \mathbf { C }}$ & $\mathbf{3 7}^{\circ} \mathbf{C}$ & $\mathbf{4 2}^{\circ} \mathbf{C}$ & $\mathbf{4 5}^{\circ} \mathbf{C}$ & $\mathbf{5 0}^{\circ} \mathbf{C}$ \\
\hline DgeReCA & ATP & $19.8 \pm 0.26$ & $26.8 \pm 0.40$ & $31.2 \pm 0.56$ & $34.1 \pm 0.78$ & $26.6 \pm 0.43$ \\
& dATP & $10.3 \pm 0.18$ & $31.6 \pm 0.63$ & $53.7 \pm 1.18$ & $65.7 \pm 1.71$ & $56.5 \pm 1.30$ \\
\hline DmuRecA & ATP & $15.6 \pm 0.23$ & $34.4 \pm 0.58$ & $55.2 \pm 1.16$ & $47.6 \pm 1.20$ & $34.5 \pm 0.62$ \\
& dATP & $24.2 \pm 0.34$ & $47.0 \pm 0.71$ & $70.3 \pm 1.76$ & $59.9 \pm 1.38$ & $43.9 \pm 0.88$ \\
\hline
\end{tabular}

Reaction conditions: $2.27 \mathrm{mM}$ ATP or dATP.

expression vector (Novagen, Beeston, Nottingham, England) digested with the same restriction enzymes. The resulting recombinant plasmid pET-30Ek/LIC-DgeRecA was used for the production of $D$. geothermalis RecA protein in E. coli.

\section{Isolation and cloning of the $D$. murrayi recA gene}

In order to obtain an internal part of the $\operatorname{rec} A$ gene from $D$. murrayi DSM 11303, sequences encoding RecA proteins of Deinococcus geothermalis DSM 1300, D. geothemalis DSM 11302, Deinococcus radiodurans R1, Thermus aquaticus YT-1, Thermus thermophilus HB8 and T. thermophilus HB27 obtained from the GenBank database were aligned using the ClustalX program, version 1.8. Based on the alignment, degenerated primers InvRecA1 5' GAGTCSGGSGGCAAGACCAC 3' and InvRecA2 5' TCCTTSCCCTGGCCSAKGC 3' were designed and synthesized. The PCR reaction was performed in the mixture containing: $0.2 \mu \mathrm{M}$ of each primer, $0.2 \mu \mathrm{g}$ of D. murrayi DSM 11303 genomic DNA, $200 \mu \mathrm{M}$ of each dNTP, $3 \mathrm{mM} \mathrm{MgCl}_{2}$ and $1 \mathrm{U}$ of DNA polymerase Hypernova (DNA-Gdańsk, Poland) in $1 \times$ buffer Hypernova (10 mM Tris- $\mathrm{HCl}$ pH 8.8, $50 \mathrm{mM}$ $\mathrm{KCl}, 0.15 \%$ Triton $\mathrm{X}-100)$. The reaction mixture was incubated for $2 \mathrm{~min}$ at $95^{\circ} \mathrm{C}$, followed by 30 cycles at $95^{\circ} \mathrm{C}$ for $1 \mathrm{~min}, 59^{\circ} \mathrm{C}$ for $1 \mathrm{~min}, 72^{\circ} \mathrm{C}$ for $1 \mathrm{~min}$, and a final incubation for $5 \mathrm{~min}$ at $72^{\circ} \mathrm{C}$. The obtained PCR product was then purified from an agarose gel band using Gel-Out kit (A\&A Biotechnology, Poland), cloned into pJET1.2/blunt vector CloneJET ${ }^{\mathrm{TM}}$ PCR Cloning Kit (Fermentas, Vilnius, Lithuania) and sequenced. Afterwards, the inverse PCR was performed for obtaining of flanking regions. The D. murrayi genomic DNA was first digested with DraI restriction endonuclease and then restriction fragments were ligated upon itself to form circles. In the second step, the PCR amplification was performed using ligation products as a template and two primers: recAInvFor 5' CCGCAAGATTGGGCAGCCCGTCAAGA 3' and recAInvRev 5' ACCCGACCGCACGAGCAGCTCCATG 3', designed on the basis of previously obtained partial sequence of D. murrayi recA gene. The reaction mixture contained also $200 \mu \mathrm{M}$ of each dNTP, $3 \mathrm{mM} \mathrm{MgCl}_{2}$ and $1 \mathrm{U}$ of DNA polymerase Hypernova (DNA-Gdańsk, Poland) in $1 \times$ buffer Hypernova. DNA amplification was performed using the following conditions: $95^{\circ} \mathrm{C}-3 \mathrm{~min}$, $\left(95^{\circ} \mathrm{C}-1.5 \mathrm{~min}, 66^{\circ} \mathrm{C}-1 \mathrm{~min}, 72^{\circ} \mathrm{C}-5 \mathrm{~min}\right) 30$ cycles and $72^{\circ} \mathrm{C}-15 \mathrm{~min}$ after the final cycle. The PCR product was purified from an agarose gel band, cloned into pJET1.2/blunt vector and sequenced. Afterwards, fragments of $D$. murrayi genomic DNA sequence were alignment and the full sequence of $\operatorname{rec} A$ gene was obtained.

The D. murrayi DSM 11303 recA gene was then amplified using the forward primer FDMRecANdeI 5' ATTACATATGAGCAAGGACAACCCCAAGGACTTC 3', and the reverse primer RDMRecAXhoI 5' TATTCTCGAGTTACTCCGCGACAGCGGGCAC 3', containing NdeI and XhoI recognition sites, respectively (underlined). The start and stop codons are bolded. The PCR reaction mixture contained: $0.2 \mu \mathrm{M}$ of each primer, $0.2 \mu \mathrm{g}$ of $D$. murrayi genomic DNA, $200 \mu \mathrm{M}$ of each dNTP, $3 \mathrm{mM} \mathrm{MgCl}_{2}$ and $1 \mathrm{U}$ of DNA polymerase Hypernova (DNA-Gdańsk, Poland) in $1 \times$ Hypernova buffer. The reaction mixture was incubated for $3 \mathrm{~min}$ at $96^{\circ} \mathrm{C}$, followed by 5 cycles at $95^{\circ} \mathrm{C}$ for $1 \mathrm{~min}, 58^{\circ} \mathrm{C}$ for 1 $\min , 72^{\circ} \mathrm{C}$ for $1 \mathrm{~min}$ and 25 cycles at $95^{\circ} \mathrm{C}$ for $1 \mathrm{~min}$, $63^{\circ} \mathrm{C}$ for $1 \mathrm{~min}, 72^{\circ} \mathrm{C}$ for $1 \mathrm{~min}$, and a final incubation for $5 \mathrm{~min}$ at $72^{\circ} \mathrm{C}$. Afterwards, PCR product was purified from an agarose gel band, cloned into pJET1.2/blunt

Table 6 Kinetic parameters for ATP and dATP hydrolysis catalyzed by DgeRecA

\begin{tabular}{ccccccc}
\hline Substrate & DNA & $\mathbf{T}\left({ }^{\mathbf{C}} \mathbf{C}\right)$ & $\mathbf{K}_{\mathbf{M}}(\mathbf{m M})$ & $\mathbf{k}_{\text {cat }}\left(\mathbf{s}^{-\mathbf{1}}\right)$ & $\mathbf{k}_{\text {cat }} / \mathbf{K}_{\mathbf{M}}\left(\mathbf{s}^{-1} \mathbf{M}^{-1}\right)$ & $\mathbf{n}^{\mathbf{a}}$ \\
\hline ATP & ssDNA & 37 & $0.56 \pm 0.018$ & $0.15 \pm 0.004$ & $2.7 \pm 0.12 \times 10^{2}$ & 2.9 \\
& ssDNA and dsDNA & 37 & $0.13 \pm 0.006$ & $0.13 \pm 0.006$ & $1.0 \pm 0.04 \times 10^{3}$ & 1.4 \\
\hline dATP & SsDNA & 37 & $0.62 \pm 0.023$ & $0.21 \pm 0.007$ & $3.3 \pm 0.10 \times 10^{2}$ \\
& SsDNA and dsDNA & 37 & $0.36 \pm 0.016$ & $0.15 \pm 0.007$ & $4.2 \pm 0.16 \times 10^{2}$ & 1.2 \\
\hline
\end{tabular}

${ }^{a}$ Hill coefficient. 
Table 7 Kinetic parameters for ATP and dATP hydrolysis catalyzed by DmuRecA

\begin{tabular}{ccccccl}
\hline Substrate & DNA & $\mathbf{T}\left({ }^{\circ} \mathbf{C}\right)$ & $\mathbf{K}_{\mathbf{M}}(\mathbf{m M})$ & $\mathbf{k}_{\text {cat }}\left(\mathbf{s}^{\mathbf{- 1}}\right)$ & $\mathbf{k}_{\text {cat }} / \mathbf{K}_{\mathbf{M}}\left(\mathbf{s}^{-\mathbf{1}} \mathbf{M}^{-\mathbf{1}}\right)$ & $\mathbf{n}^{\mathbf{a}}$ \\
\hline ATP & ssDNA & 37 & $0.31 \pm 0.009$ & $0.13 \pm 0.004$ & $4.3 \pm 0.18 \times 10^{2}$ \\
& ssDNA and dsDNA & 37 & $0.28 \pm 0.009$ & $0.067 \pm 0.0021$ & $2.4 \pm 0.08 \times 10^{2}$ & 1.1 \\
\hline dATP & ssDNA & 37 & $0.28 \pm 0.007$ & $0.14 \pm 0.004$ & $5.0 \pm 0.25 \times 10^{2}$ \\
& ssDNA and dsDNA & 37 & $0.22 \pm 0.007$ & $0.073 \pm 0.0023$ & $3.4 \pm 0.05 \times 10^{2}$ & 1.0 \\
\hline
\end{tabular}

${ }^{a}$ Hill coefficient

vector and sequenced. The obtained pJET-NdeI-DmuRecA-XhoI plasmid was then digested with NdeI and $X h o I$ endonucleases, and the DNA fragment containing the $\operatorname{rec} A$ gene was cloned into pET-30 Ek/LIC expression vector (Novagen) digested with the same restriction enzymes. The resulting recombinant plasmid pET-30Ek/ LIC-DmuRecA was used for the production of D. murrayi $\operatorname{Rec} A$ protein in $E$. coli.

Production and purification of recombinant DgeRecA and DmuRecA proteins

Overproduction of $D g e$ RecA and DmuRecA proteins was performed in the E. coli BLR(DE3) cells (Novagen) carrying the pET-30Ek/LIC-DgeRecA or pET-30Ek/LICD$m u$ RecA plasmids. Cells were grown at $37^{\circ} \mathrm{C}$ in $750 \mathrm{ml}$ LB medium ( $1 \%$ peptone $K, 0.5 \%$ yeast extract, $1 \%$
$\mathrm{NaCl}$ ) containing $20 \mu \mathrm{g} / \mathrm{ml}$ of kanamycin. At $\mathrm{OD}_{600} 0.5$ IPTG was added to the final concentration of $1 \mathrm{mM}$ and cultivation was continued for 4 hours. Subsequently, cultures were centrifuged $\left(4612 \times g, 10 \mathrm{~min}, 4^{\circ} \mathrm{C}\right)$ and pellets were resuspended in $75 \mathrm{ml}$ of buffer $A_{1}(20 \mathrm{mM}$ potassium phosphate buffer $\mathrm{pH} 6.0,50 \mathrm{mM} \mathrm{KCl}, 1 \mathrm{mM}$ EDTA, $1 \mathrm{mM}$ DTT) in the case of $D g e$ RecA protein production or buffer $\mathrm{A}_{2}(20 \mathrm{mM}$ potassium phosphate buffer $\mathrm{pH}$ 6.5, $50 \mathrm{mM} \mathrm{KCl,} 1 \mathrm{mM}$ EDTA, 1 mM DTT ) for the DmuRecA. Samples were sonicated seven times for $30 \mathrm{~s}$ at $0^{\circ} \mathrm{C}$ and centrifuged $\left(4612 \times g, 10 \mathrm{~min}, 4^{\circ} \mathrm{C}\right)$. The supernatant containing $D g e$ RecA protein was heattreated at $60^{\circ} \mathrm{C}$ for $20 \mathrm{~min}$, cooled on ice and centrifuged again $\left(18000 \times g, 30 \mathrm{~min}, 4^{\circ} \mathrm{C}\right)$.

DgeRecA and DmuRecA proteins were then purified using Fractogel EMD DEAE column (Merck, Darmstadt,
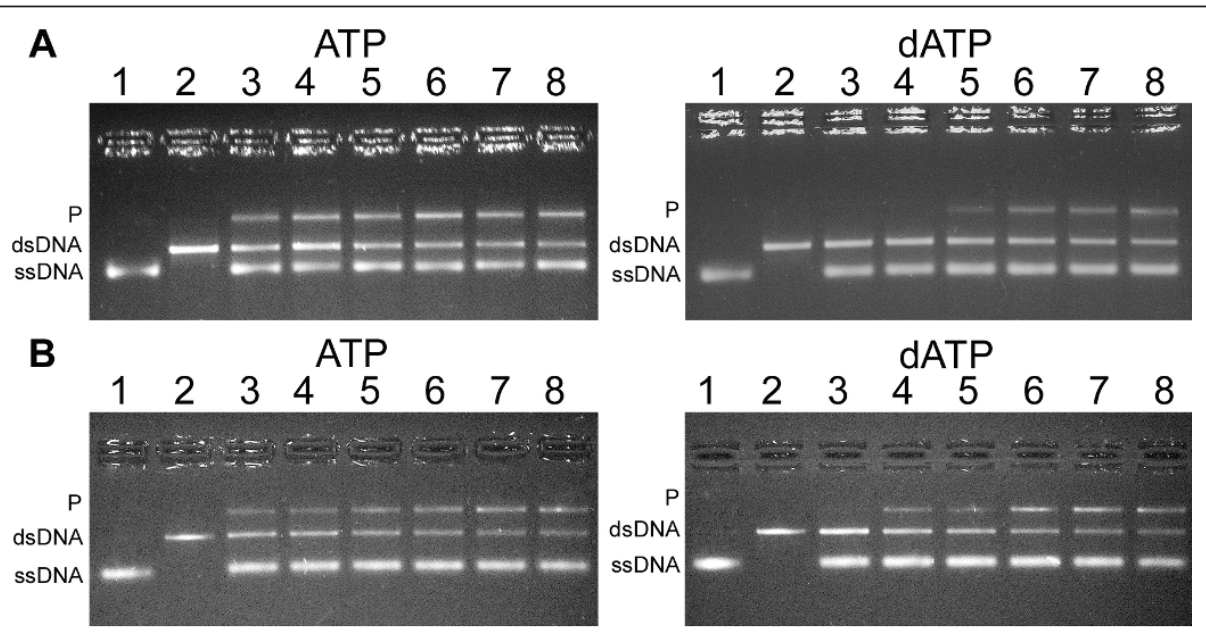

C

D
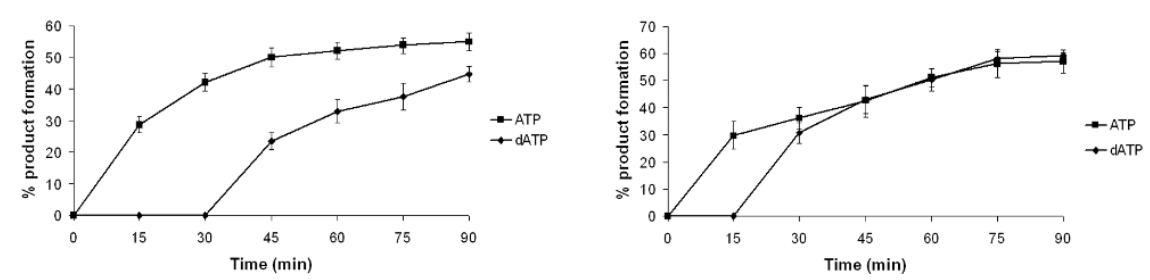

Figure 7 DNA strand exchange promoted by $\operatorname{DgeRecA}(A, C)$ and $\operatorname{DmuRecA}(\mathrm{B}, \mathrm{D})$ proteins. Panels A and B: lane $1-\mathrm{M} 13 \mathrm{mp} 18$ ssDNA, lane 2 - M13mp18 dsDNA digested with Smal, lane 3 - reaction products formed after $15 \mathrm{~min}$, lane 4 - reaction products formed after 30 min, lane 5 - reaction products formed after $45 \mathrm{~min}$, lane 6 - reaction products formed after $60 \mathrm{~min}$, lane 7 - reaction products formed after 75 min, lane 8 - reaction products formed after 90 min. P - nicked circular dsDNA. Panels C and D: plots of the quantified product formation for the reactions in panels $\mathrm{A}$ and $\mathrm{B}$. 
Germany) equilibrated with buffer $A_{1}$ or $A_{2}$, respectively. RecA proteins were eluted with linear gradient of 0.05-1.5 M KCl in the appropriate buffer. Fractions containing $D$. geothermalis or $D$. murrayi RecA were pooled, dialyzed against buffer $\mathrm{A}_{1}$ or $\mathrm{A}_{2}$ and loaded onto ResourceQ column (Amersham Biosciences AB, Uppsala, Sweden). Elution was performed by linear gradient of $0.05-0.425 \mathrm{M} \mathrm{KCl}$ in buffer $\mathrm{A}_{1}$ or $\mathrm{A}_{2}$. Fractions containing RecA proteins were dialyzed against buffer $\mathrm{A}_{1}$ or $\mathrm{A}_{2}$ once again and purified using MonoQ column (Amersham Biosciences AB). DgeRecA and DmuRecA were eluted with linear gradient of 0.05-0.35 $\mathrm{M} \mathrm{KCl}$ in appropriate buffer. Collected fractions containing purified RecA proteins were then checked for nucleases contaminations by incubating them with M13mp18 RFI DNA (24 $\mu \mathrm{M}$ of nucleotides), linear dsDNA M13mp18 (24 $\mu \mathrm{M}$ of nucleotides) and circular ssDNA M13mp18 (12 $\mu \mathrm{M}$ of nucleotides) in the $20 \mathrm{mM}$ potassium phosphate buffer $\mathrm{pH} 7.5$ containing $10 \mathrm{mM} \mathrm{MgCl}$. The concentration of RecA proteins was $10 \mu \mathrm{M}$. Reaction mixtures were incubated at $37^{\circ} \mathrm{C}$ for $2 \mathrm{~h}$ and then EDTA, SDS and Proteinase $\mathrm{K}$ were added to the final concentrations of $10 \mathrm{mM}, 1 \%$ and $2 \mathrm{mg} / \mathrm{ml}$, respectively. Samples were incubated at room temperature for 30 min and separated by electrophoresis in 1\% agarose gels with ethidium bromide. DNAs were also incubated with Proteinase $\mathrm{K}$ only, as a control sample. We did not observe any exo- or endonuclease activities neither in RecA proteins preparations nor in Proteinase K. Afterwards the RecA proteins were dialyzed against $100 \mathrm{mM}$ $\left(\mathrm{NH}_{4}\right) \mathrm{HCO}_{3}$ and lyophilized for long-time storage.

The purity of proteins was investigated by SDS-PAGE. The concentration of RecA proteins at every step of production and purification was measured by Bradford method [54]. Protein concentration in the samples for biochemical tests was determined by $\mathrm{A}_{280 \mathrm{~nm}}$ using an extinction coefficient of $11,920 \mathrm{M}^{-1} \mathrm{~cm}^{-1}$, which was calculated from the amino acid sequences of $D g e \operatorname{Rec} A$ and $D m u$ RecA proteins.

\section{Estimation of the native molecular mass}

The molecular mass of DgeRecA and DmuRecA proteins were estimated using analytical gel filtration chromatography. Samples containing various concentrations of purified proteins were loaded onto Superdex 200 HR 10/30 column (Amersham Biosciences AB) equilibrated with 25 $\mathrm{mM}$ potassium phosphate buffer $\mathrm{pH} 7.5$ containing $1.0 \mathrm{M}$ $\mathrm{KCl}$ and eluted with the same buffer at a flow rate of 0.5 $\mathrm{ml} / \mathrm{min}$. The elution profiles were monitored by recording the absorbance at $214 \mathrm{~nm}$. The molecular weights of DgeRecA and DmuRecA oligomers were determined by comparison with those of standard proteins: thyroglobulin (669 kDa), apoferritin (443 kDa), $\beta$-amylase $(200 \mathrm{kDa})$, alcohol dehydrogenase $(150 \mathrm{kDa})$, bovine serum albumin $(66 \mathrm{kDa})$ and carbon anhydrase $(29 \mathrm{kDa})$.

\section{ssDNA binding activity}

The ability of $D g e$ RecA and DmuRecA proteins to bind ssDNA was investigated by electrophoretic mobility shift of fluorescein 5 '-end-labelled oligo $(\mathrm{dT})_{35}$ nucleotides. $25 \mu \mathrm{l}$ reaction mixtures containing $5.6 \mu \mathrm{M}$ (nucleotides) oligo $(\mathrm{dT})_{35}, 110 \mu \mathrm{M}$ ATP- $\gamma-\mathrm{S}, 300 \mu \mathrm{M}$ ATP, from 0 to $10 \mathrm{mM} \mathrm{MgCl}$ and $9 \mu \mathrm{M}$ RecA protein in $20 \mathrm{mM}$ potassium phosphate buffer $\mathrm{pH} 7.5$ were incubated at 25$75^{\circ} \mathrm{C}$ for $30 \mathrm{~min}$ in the dark. Afterwards samples were separated by electrophoresis in $0.8 \%$ agarose gels. Results were visualized using UV transilluminator.

\section{dsDNA binding activity}

The ability of DgeRecA and DmuRecA proteins to bind dsDNA was investigated by electrophoretic mobility shift of 600 bp PCR product ( $\lambda$ DNA amplified using 5' GGACAAGGTCGCTGAAGCCTTCG $3^{\prime}$ and 5' TCCTGACGGGCGGTATATTTCTCC 3' primers). 25 $\mu \mathrm{l}$ reaction mixtures containing $30 \mu \mathrm{M}$ (nucleotides) dsDNA or $30 \mu \mathrm{M}$ dsDNA and $14 \mu \mathrm{M}$ ssDNA (fluorescein 5'-end-labelled oligo(dT) $\left.{ }_{35}\right), 180 \mu \mathrm{M}$ ATP- $\gamma-\mathrm{S}, 500$ $\mu \mathrm{M}$ ATP, 0 or $10 \mathrm{mM} \mathrm{MgCl}_{2}$ and $12 \mu \mathrm{M}$ RecA protein in $20 \mathrm{mM}$ potassium phosphate buffer $\mathrm{pH} 7.5$ were incubated at $37^{\circ} \mathrm{C}$ for $30 \mathrm{~min}$. Afterwards samples were separated by electrophoresis in $0.8 \%$ agarose gels containing ethidium bromide. Results were visualized using UV transilluminator.

\section{Thermostability of the RecA proteins}

The thermostability of DgeRecA and DmuRecA was determined by ssDNA binding activity after incubation of proteins at various temperatures for a set of time periods. The samples containing $11.8 \mu \mathrm{M}$ RecA protein and 0 or $10 \mathrm{mM} \mathrm{MgCl}_{2}$ in $20 \mathrm{mM}$ potassium phosphate buffer $\mathrm{pH} 7.5$ were incubated at $50-80^{\circ} \mathrm{C}$ for $10 \mathrm{~s}$ to $180 \mathrm{~min}$, cooled on ice and centrifuged $(13500 \times g, 10$ min). Aliquots $(19 \mu \mathrm{l})$ were then taken and fluorescein 5 '-end-labelled oligo $(\mathrm{dT})_{35}$ nucleotides, ATP, ATP- $\gamma-\mathrm{S}$ and $\mathrm{MgCl}_{2}$ were added to the concentrations of $5.6 \mu \mathrm{M}$, $300 \mu \mathrm{M}, 110 \mu \mathrm{M}$ and $10 \mathrm{mM}$ in the final volume of $25 \mu \mathrm{l}$, respectively. Subsequently reaction mixtures were incubated at $37^{\circ} \mathrm{C}$ for $30 \mathrm{~min}$ in the dark and separated by electrophoresis in $0.8 \%$ agarose gels. Results were visualized using UV transilluminator.

\section{ATPase assay}

Hydrolysis of ATP (or dATP) by DgeRecA and DmuRecA was monitored by an enzyme coupled method. Regeneration of ATP from ADP and phosphoenolpyruvate catalyzed by pyruvate kinase was coupled with the conversion of NADH to $\mathrm{NAD}^{+}$catalyzed by lactate dehydrogenase, which was monitored by a decrease in absorbance at $355 \mathrm{~nm}$. The absorbance was measured using PerkinElmer multilabel plate reader Victor $^{3} \mathrm{~V}$ 
(Centre of Excellence ChemBioFarm, Gdańsk University of Technology, Gdańsk, Poland).

The reaction mixtures consisted of: $3.03 \mu \mathrm{M}$ RecA protein, $11.56 \mathrm{mM} \mathrm{MgCl}_{2}, 1.25 \mathrm{U}$ of lactate dehydrogenase from rabbit muscle, $0.75 \mathrm{U}$ of pyruvate kinase from rabbit muscle, $3.3 \mathrm{mM} \mathrm{NADH}, 2.27 \mathrm{mM}$ PEP, 0.38-2.27 mM ATP (or dATP) and $20 \mathrm{mM}$ Tris- $\mathrm{HCl}$ buffer $\mathrm{pH} 7.5$ to the end volume of $75 \mu \mathrm{l}$. Reactions were carried out in the absence of DNA and in the presence of $12.16 \mu \mathrm{M}$ (nucleotides) ssDNA of SygB1a oligonucleotide 5' CGTTCGAAACGATGAGGAAGACTTATTGGCTGA TGGCGCTTTTCGCGGTGCTCATGTTCCCTGAAAA GTTCCTTTGGGGT 3' (80 nt) and/or 1,312 $\mu \mathrm{M}$ (nucleotides) of XbaI-linearized dsDNA of pBADTOPO $\beta$ AQa plasmid (5727 bp) containing complementary sequence to the SygB1a oligonucleotide. ATP (or dATP) hydrolysis reactions were performed at $32,37,42,45$ and $50^{\circ} \mathrm{C}$.

\section{DNA strand exchange reactions}

RecA-dependent DNA strand exchange reactions were carried out between circular ssDNA of M13mp18 and linear dsDNA of M13mp18 obtained by SmaI digestion. All reactions were carried out in solutions containing 20 $\mathrm{mM}$ Tris- $\mathrm{HCl}$ buffer $\mathrm{pH} 7.5,5 \mu \mathrm{M}$ RecA protein, $9 \mu \mathrm{M}$ (nucleotides) ssDNA, $18 \mu \mathrm{M}$ (nucleotides) dsDNA, 0.3 $\mu \mathrm{M}$ DgeSSB protein [44], $1.2 \mathrm{mM}$ DTT, $10 \mathrm{mM} \mathrm{MgCl}_{2}$, $3 \mathrm{mM}$ ATP and an ATP-regenerating system (0.5 U pyruvate kinase from rabbit muscle, $3 \mathrm{mM}$ phosphoenolpyruvate) in $25 \mu$ l. A preincubation of ssDNA with DgeRecA at $45^{\circ} \mathrm{C}$ or with DmuRecA at $42^{\circ} \mathrm{C}$ for $5 \mathrm{~min}$ was followed by addition of ATP or dATP and SSB. After an additional 5 min incubation, linear dsDNA was added to start the strand exchange reactions. The reactions were carried out at $45^{\circ} \mathrm{C}$ when $D g e$ RecA was used or at $42^{\circ} \mathrm{C}$ in the case of DmuRecA for $15,30,45,60$, 75 and 90 min and stopped by addition of EDTA, SDS and Proteinase $\mathrm{K}$ to the final concentrations of $10 \mathrm{mM}$, $1 \%$ and $2 \mathrm{mg} / \mathrm{ml}$, respectively. Samples were incubated at room temperature for 30-90 min and then separated by electrophoresis in $0.8 \%$ agarose gels. Results were visualized and photographed with UV light using VersaDoc $^{\mathrm{TM}}$ Imaging System (Bio-Rad Laboratories, Hercules, California, USA) after staining of gels with ethidium bromide. The DNA bands were quantified with Quantity One software, version 4.3.1 (Bio-Rad Laboratories). The band corresponding to nicked circular dsDNA product was quantified as the fraction of the total DNA in a given gel lane, excluding the band corresponding to the ssDNA. In the case of inverse DNA strand exchange reactions, RecA proteins were preincubated with the linear dsDNA and ATP or dATP for 15-60 min. The ssDNA was then added to start the reactions, and the SSB was added 5 min later.

\section{Abbreviations}

DSB: DNA double-strand break; DgeRecA: Deinococcus geothermalis RecA protein; DmuRecA: Deinococcus murrayi RecA protein; DraRecA: Deinococcus radiodurans RecA protein; TthRecA: Thermus thermophilus RecA protein; EcoRecA: Escherichia coli RecA protein; DgeSSB: Deinococcus geothermalis single-stranded DNA-binding protein; ATP- $\gamma$-S: Adenosine 5'-[ $\gamma$-thio] triphosphate; IPTG: Isopropyl $\beta$-D-thiogalactopyranoside.

\section{Acknowledgements}

This work was supported by the Polish Ministry of Science and Higher Education Grant N N302 067934 to J.K. We thank Dr. P. Filipkowski for pBADDgeSSB plasmid used in this study.

\section{Authors' contributions}

MW participated in the design of the study, partially characterized of RecA proteins and drafted the manuscript; PH obtained and partially characterized of RecA proteins; BK partially characterized of RecA proteins; JK corrected and edited the final version of manuscript. All authors read and approved the final manuscript.

Received: 24 January 2011 Accepted: 22 April 2011 Published: 22 April 2011

\section{References}

1. Ferreira AC, Nobre MF, Rainey FA, Silva MT, Wait R, Burghardt J, Chung AP, da Costa MS: Deinococcus geothermalis sp. nov. and Deinococcus murrayi sp. nov., two extremely radiation-resistant and slightly thermophilic species from hot springs. Int J Syst Bacteriol 1997, 47:939-947.

2. Väisänen OM, Weber A, Bennasar A, Rainey FA, Busse HJ, SalkinojaSalonen MS: Microbial communities of printing paper machines. J App/ Microbiol 1998, 84:1069-1084.

3. Kolari M, Nuutinen J, Salkinoja-Salonen MS: Mechanisms of biofilm formation in paper machine by Bacillus species: the role of Deinococcus geothermalis. J Ind Microbiol Biotechnol 2001, 27:343-351.

4. Peltola M, Kanto Öqvist C, Ekman J, Kosonen M, Jokela S, Kolari M, Korhonen P, Salkinoja-Salonen M: Quantitative contributions of bacteria and of Deinococcus geothermalis to deposits and slimes in paper industry. J Ind Microbiol Biotechnol 2008, 35:1651-1657.

5. Zahradka K, Slade D, Bailone A, Sommer S, Averbeck D, Petranovic M, Lindner $A B$, Radman M: Reassembly of shattered chromosomes in Deinococcus radiodurans. Nature 2006, 443:569-573.

6. Slade $D$, Lindner $A B$, Paul G, Radman M: Recombination and replication in DNA repair of heavily irradiated Deinococcus radiodurans. Cell 2009, 136:1044-1055.

7. Repar J, Cvjetan S, Slade D, Radman M, Zahradka D, Zahradka K: RecA protein assures fidelity of DNA repair and genome stability in Deinococcus radiodurans. DNA Repair 2010, 9:1151-1161.

8. Shigenobu S, Watanabe H, Masahira Hattori M, Sakaki Y, Ishikawa H: Genome sequence of the endocellular bacterial symbiont of aphids Buchnera sp. APS. Nature 2000, 407:81-86.

9. Gil R, Silva FJ, Zientz E, Delmotte F, González-Candelas F, Latorre A, Rausell C, Kamerbeek J, Gadau J, Hölldobler B, van Ham RCHJ, Gross R, Moya A: The genome sequence of Blochmannia floridanus: comparative analysis of reduced genomes. Proc Natl Acad Sci USA 2003, 100:9388-9393.

10. Akman L, Yamashita A, Watanabe H, Oshima K, Shiba T, Hattori M, Aksoy S: Genome sequence of the endocellular obligate symbiont of tsetse flies, Wigglesworthia glossinidia. Nat Genet 2002, 32:402-407.

11. Kuwahara H, Yoshida T, Takaki Y, Shimamura S, Shinro Nishi S, Maiko Harada M, Kazuyo Matsuyama K, Takishita K, Kawato M, Uematsu K, Fujiwara Y, Sato T, Kato C, Kitagawa M, Kato I, Maruyama T: Reduced genome of the thioautotrophic intracellular symbiont in a deep-sea clam, Calyptogena okutanii. Curr Biol 2007, 17:881-886.

12. Newton ILG, Woyke T, Auchtung TA, Dilly GF, Dutton RJ, Fisher MC, Fontanez KM, Lau E, Stewart FJ, Richardson PM, Barry KW, Saunders E, Detter JC, Wu D, Eisen JA, Cavanaugh CM: The Calyptogena magnifica chemoautotrophic symbiont genome. Science 2007, 315:998-1000.

13. Kuwahara H, Takaki Y, Yoshida T, Shimamura S, Takishita K, Reimer JD, Kato C, Maruyama T: Reductive genome evolution in chemoautotrophic intracellular symbionts of deep-sea Calyptogena clams. Extremophiles 2008, 12:365-374. 
14. Seitz EM, Brockman JP, Sandler SJ, Clark AJ, Kowalczykowski SC: RadA protein is an archaeal RecA protein homolog that catalyzes DNA strand exchange. Genes Dev 1998, 12:1248-1253.

15. Ogawa T, Yu X, Shinohara A, Egelman EH: Similarity of the yeast RAD51 filament to the bacterial RecA filament. Science 1993, 259:1896-1899.

16. Benson FE, Stasiak A, West SC: Purification and characterization of the human Rad51 protein, an analogue of E. coli RecA. Embo J 1994 13:5764-5771.

17. Fujisawa $H$, Yonesaki $T$, Minagawa $T$ : Sequence of the $T 4$ recombination gene, uvs $X$, and its comparison with that of the recA gene of Escherichia coli. Nucleic Acids Res 1985, 13:7473-7481.

18. Kowalczykowski SC, Dixon DA, Eggleston AK, Lauder SD, Rehrauer WM: Biochemistry of homologous recombination in Escherichia coli. Microbiol Rev 1994, 58:401-465.

19. Kuzminov A: Recombinational repair of DNA damage in Escherichia coli and bacteriophage $\lambda$. Microbiol Mol Biol Rev 1999, 63:751-813.

20. Lusetti SL, Cox MM: The bacterial RecA protein and the recombinational DNA repair of stalled replication forks. Annu Rev Biochem 2002, 71:71-100.

21. Little JW: Mechanism of specific LexA cleavage - autodigestion and the role of RecA coprotease. Biochimie 1991, 73:411-421.

22. Shinagawa $\mathrm{H}$ : SOS response as an adaptative response to DNA damage in prokaryotes. EXS 1996, 77:221-235.

23. Burckhardt SE, Woodgate $\mathrm{R}$, Scheuremann RH, Echols $\mathrm{H}$ : UmuD mutagenesis protein of Escherichia coli: overproduction, purification, and cleavage by RecA. Proc Natl Acad Sci USA 1988, 85:1811-1815.

24. Nohmi T, Battista JR, Dodson LA, Walker GC: RecA-mediated cleavage activates UmuD for mutagenesis: mechanistic relationship between transcriptional derepression and posttranslational activation. Proc Natl Acad Sci USA 1988, 85:1816-1820.

25. Shinagawa $H$, Iwasaki $T$, Kato $T$, Nakata A: RecA-protein dependent cleavage of UmuD protein and SOS mutagenesis. Proc Natl Acad Sci USA 1988, 85:1806-1810.

26. Bruck I, Woodgate R, McEntee K, Goodman MF: Purification of a soluble UmuD'C complex from Escherichia coli: cooperative binding of UmuD'C to single-stranded DNA. J Biol Chem 1996, 271:10767-10774.

27. Tang M, Shen X, Frank EG, O'Donnell M, Woodgate R, Goodman MF: UmuD ${ }_{2} \mathrm{C}$ is an error-prone DNA polymerase, Escherichia coli pol V. Proc Natl Acad Sci USA 1999, 96:8919-8924.

28. Jiang Q, Karata K, Woodgate R, Cox MM, Goodman MF: The active form of DNA polymerase $\mathrm{V}$ is $\mathrm{UmuD}_{2} \mathrm{C}$ C-RecA-ATP. Nature 2009, 460:359-363.

29. Egelman EH, Stasiak A, Structure of helical RecA-DNA complexes: Complexes formed in the presence of ATP-gamma-S or ATP. J Mol Biol 1986, 191:677-697.

30. Di Capua E, Schnarr M, Ruigrok RWH, Lindner P, Timmins PA: Complexes of RecA protein in solution. A study by small angle neutron scattering. J Mol Biol 1990, 214:557-570.

31. Nordén B, Elvingson $C$, Kubista $M$, Sjöberg B, Ryberg $H$, Ryberg $M$ Mortensen K, Takahashi M: Structure of RecA-DNA complexes studied by combination of linear dichroism and small-angle neutron scattering measurements on flow-oriented samples. J Mol Biol 1992, 226:1175-1191.

32. $\mathrm{Yu} X$, Egelman EH: Structural data suggest that the active and inactive forms of the RecA filament are not simply interconvertible. J Mol Biol 1992, 227:334-346

33. Weinstock GM, McEntee K, Lehman IR: Hydrolysis of nucleoside triphosphates catalyzed by the recA protein of Escherichia coli. Characterization of ATP hydrolysis. J Biol Chem 1981, 256:8829-8834

34. Arenson TA, Tsodikov OV, Cox MM: Quantitative analysis of the kinetics of end-dependent disassembly of RecA filaments from ssDNA. J Mol Biol 1999, 288:391-401.

35. Honigberg SM, Gonda DK, Flory J, Radding CM: The pairing activity of stable nucleoprotein filaments made from recA protein, single-stranded DNA, and adenosine 5'-(gamma-thio)triphosphate. J Biol Chem 1985 260:11845-11851.

36. Menetski JP, Bear DG, Kowalczykowski SC: Stable DNA heteroduplex formation catalyzed by the Escherichia coli RecA protein in the absence of ATP hydrolysis. Proc Natl Acad Sci USA 1990, 87:21-25

37. Cox MM, Lehman IR: RecA protein-promoted DNA strand exchange. Stable complexes of recA protein and single-stranded DNA formed in the presence of ATP and single-stranded DNA binding protein. $J$ Biol Chem 1982, 257:8523-8532.
38. Chow SA, Chiu SK, Wong BC: RecA protein-promoted homologous pairing and strand exchange between intact and partially single-stranded duplex DNA. J Mol Biol 1992, 223:79-93.

39. Jain SK, Cox MM, Inman RB: On the role of ATP hydrolysis in RecA protein-mediated DNA strand exchange. III. Unidirectional branch migration and extensive hybrid DNA formation. J Biol Chem 1994 269:20653-20661.

40. Kim Jl, Cox MM, Inman RB: On the role of ATP hydrolysis in RecA proteinmediated DNA strand exchange. I. Bypassing a short heterologous insert in one DNA substrate. J Biol Chem 1992, 267:16438-16443.

41. Shan Q, Cox MM, Inman RB: DNA strand exchange promoted by RecA K72R. Two reaction phases with different $\mathrm{Mg}^{2+}$ requirements. J Biol Chem 1996, 271:5712-5724.

42. Kim Jl, Cox MM, Inman RB: On the role of ATP hydrolysis in RecA proteinmediated DNA strand exchange. II. Four-strand exchanges. J Biol Chem 1992, 67:16444-16449.

43. Kim Jl, Cox MM: The RecA protein of Deinococcus radiodurans and Escherichia coli promote DNA strand exchange via inverse pathways. Proc Natl Acad Sci USA 2002, 99:7917-7921.

44. Filipkowski $P$, Duraj-Thatte A, Kur J: Novel thermostable single-stranded DNA-binding protein (SSB) from Deinococcus geothermalis. Arch Microbiol 2006, 186:129-137.

45. Brenner SL, Zlotnick A, Griffith JD: RecA protein self-assembly. Multiple discrete aggregation states. J Mol Biol 1988, 204:959-972.

46. Brenner SL, Zlotnick A, Stafford WF III: RecA protein self-assembly. II. Analytical equilibrium ultracentrifugation studies of the entropy-driven self-association of RecA. J Mol Biol 1990, 216:949-964.

47. Yu X, Angov E, Camerini-Otero RD, Egelman EH: Structural polymorphism of the RecA protein from the thermophilic bacterium Thermus aquaticus. Biophys J 1995, 69:2728-2738.

48. Masui R, Mikawa T, Kato R, Kuramitsu S: Characterization of the oligomeric states of RecA protein: monomeric RecA protein can form a nucleoprotein filament. Biochemistry 1998, 37:14788-14797.

49. Kim Jl, Sharma AK, Abbott SN, Wood EA, Dwyer DW, Jambura A, Minton KW, Inman RB, Daly MJ, Cox MM: RecA protein from the extremely radioresistant bacterium Deinococcus radiodurans: expression, purification, and characterization. J Bacteriol 2002, 184:1649-1660.

50. Kim J: Analysis of double stranded DNA-dependent activities of Deinococcus radiodurans RecA protein. J Microbiol 2006, 44:508-514.

51. Kato R, Kuramitsu S: Characterization of thermostable RecA protein and analysis of its interaction with single-stranded DNA. Eur J Biochem 1999, 259:592-601.

52. Sghaier H, Satoh K, Ohba H, Narumi I: Assessing the role of RecA protein in the radioresistant bacterium Deinococcus geothermalis. Afr J Bichem Res 2010, 4:111-118.

53. Bentchikou E, Servant $P$, Coste $G$, Sommer S: A major role of the RecFOR pathway in DNA double-strand-break repair through ESDSA in Deinococcus radiodurans. PLoS Genetics 2010, 6:e1000774.

54. Bradford MM: A rapid and sensitive method for the quantitation of microgram quantities of protein utilizing the principle of protein-dye binding. Anal Biochem 1976, 72:248-254

doi:10.1186/1471-2199-12-17

Cite this article as: Wanarska et al:: RecA Proteins from Deinococcus geothermalis and Deinococcus murrayi - Cloning, Purification and Biochemical Characterisation. BMC Molecular Biology 2011 12:17. 